
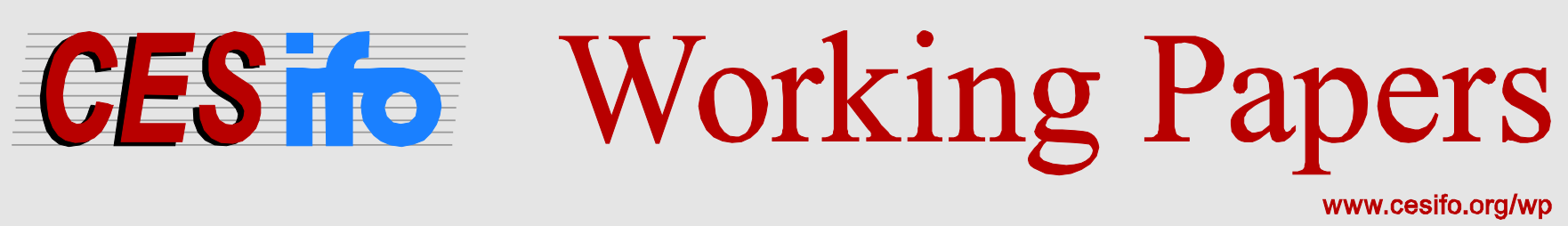

\title{
The Modality of Fiscal Consolidation and Current Account Adjustment
}

\author{
Antonis Adam \\ Thomas Moutos
}

\author{
CESIFO WORKING PAPER NO. 5451 \\ CATEgory 6: Fiscal Policy, Macroeconomics AND GrowTH \\ JULY 2015
}

Presented at CESifo - Delphi Conference on Current Account Adjustments, May 2015

An electronic version of the paper may be downloaded

- from the SSRN website:

- from the RePEc website:

- from the CESifo website:

www.SSRN.com

www.RePEc.org

www.CESifo-group.org/wp 


\title{
The Modality of Fiscal Consolidation and Current Account Adjustment
}

\begin{abstract}
In this paper we argue that supply-side adjustments (i.e. the reallocation of productive resources between the traded and non-traded sectors) can be an important determinant of the output costs of current account adjustment. The argument relies on the fact that tax evasion is more prevalent in the non-traded sector, which is dominated by services and the self-employed. Heavy reliance on tax-based fiscal consolidations induces a reallocation of economic activity towards the nontraded sector, thus requiring a larger decline in domestic absorption (and output) per unit of improvement in the current account balance. Using IMF data for the period 1980-2011 we find that budget consolidations which rely more on tax increases than on spending decreases will be associated with larger output costs per unit of current account improvement.
\end{abstract}

JEL-Code: E620, F320, F410.

Keywords: current account adjustment, fiscal consolidation, sacrifice ratio, tax evasion.

Antonis Adam

Department of Economics

University of Ioannina

P.O. Box 1186

Greece - Ioannina 45110

aadam@cc.uoi.gr
Thomas Moutos

Department of International and

European Economic Studies

AUEB

Patission 76

Greece-Athens 10434

tmoutos@aueb.gr

We wish to thank Sarantis Kalyvitis, Margarita Katsimi and conference participants at the CESifo-Delphi Conference on "Current Account Adjustments" and at EBES 2015 Conference for useful comments and suggestions. 


\section{Introduction}

According to the twin deficits hypothesis there is a positive relationship between (government) budget deficits and current account deficits (e.g. a lower budget deficit is associated with a lower current account deficit). ${ }^{1}$ This suggests that in economies plagued with both budget and current account deficits, domestic policymakers and international authorities charged with enforcing credible adjustment programmes may rest their hopes for addressing both types of deficits by focusing their efforts at budget consolidation. However, these types of adjustments have often consequences for real economic performance. Indeed, the literature on current account reversals (defined as a sustained current account improvement of deficit countries) suggests that these often entail substantial output losses, although this is not a unanimous conclusion. $^{2}$

This literature has also studied whether the exchange rate regime affects the extent of output losses during current account reversals. Indeed, Keynes (1931) and Friedman (1953) argued that (nominal) exchange rate flexibility would allow countries to experience a smoother adjustment process by functioning as external shock absorbers. ${ }^{3}$ This is because, in practice, both prices and wages are relatively sticky compared to the nominal exchange rate (Mussa, 1986), thus under a fixed exchange rate regime most of the adjustment burden may have to be borne by changes in economic activity, potentially leading to a more pronounced slowdown. Indeed, Edwards (2004a) and Edwards (2004b) found in a sample of mainly developing

\footnotetext{
${ }^{1}$ Such a prediction emerges in many models, e.g., in the Mundell-Fleming model under flexible exchange rates and in general equilibrium models with both Ricardian and non-Ricardian features (Obstfeld and Rogoff, 1996; Roubini and Wachtel, 1998). However, the empirical evidence is inconclusive. On the one hand, and on the basis of a historical analysis of documented fiscal policy changes, Bluedorn and Leigh (2011) conclude that the current account responds substantially to fiscal policy-a fiscal consolidation of 1 percent of GDP typically improves an economy's current account balance by about 0.6 percent of GDP. On the other hand, many studies examining the link between fiscal and external deficits have produced very mixed and inconclusive results (e.g., Chinn and Ito, 2007; Kim and Roubini, 2008; Abbas et al, 2010).

${ }^{2}$ Milesi-Ferretti and Razin (2000) did not uncover any systematic relationship between current account reversals and economic performance, although output performance was very heterogeneous. Freund (2005 found that reversals in industrial countries are generally accompanied by a decline in GDP growth; this finding emerges also in Freund and Warnock (2007). Debelle and Galati (2005) find that reduction in current account deficits are associated with significantly slower output growth for industrial countries, but argue that current account adjustment likely reflects the outcome of a slowdown in domestic growth rather than vice versa. In contrast, Edwards (2004a, 2004b, 2007) presents results suggesting that current account adjustments do lead to slower output growth for both developing and industrial countries.

${ }^{3}$ However, Chinn and Wei (2013) have disputed the empirical validity of this belief, i.e. they found no evidence In support of the hypothesis that the current account reversion to its long run equilibrium is faster under flexible exchange rate regimes.
} 
economies that current account reversals lead to lower GDP growth only under hard pegged and intermediate exchange rate systems.

In this paper we argue that the modality of budget consolidation (i.e. tax-based versus spending-based) efforts can also be an important determinant for how costly are current account adjustment episodes in terms of output losses. ${ }^{4}$ More specifically, we claim that efforts to improve the current account through an improvement in the (government's) budget balance, will cause a larger decline in output per unit of improvement in the current account balance we call this the sacrifice ratio - if they are based more on tax hikes than on spending decreases.

The thrust of our argument is based on noting that tax evasion is more prevalent in the nontraded sector -which in many countries is dominated by the self-employed - than in the traded sector. This implies that the effective after-tax relative price of the traded sector is smaller than what one would surmise by looking simply at the prices of the two sectors, thus attracting fewer resources in the traded sector. It also implies that a given reduction in domestic demand (i.e. absorption) will have a different effect on the current account depending on whether it is achieved through a rise in tax rates or decreases in government spending. This is because, unlike a cut in government spending, a rise in the statutory tax rate(s) - for given rates of tax evasion in the two sectors - increases the relative attractiveness of the non-traded sector, decreases the production of traded goods and, it requires a larger decline in domestic consumption of traded goods and output in order to achieve a given improvement in the current account balance.

In Section 2 we elaborate on our hypothesis that efforts to reduce current account deficits which rely on tax-based budget consolidations will have a larger sacrifice ratio than those relying on spending decreases. We then proceed in Section 3 to explain our method for identifying current account adjustment episodes and of calculating the associated sacrifice ratios. Using IMF data for 161 countries for the period 1980-2012, we identify 82 current account adjustment episodes, for 51 of which we have the necessary data for the fiscal policy

\footnotetext{
${ }^{4}$ The modality of budget consolidation efforts has been singled out by many authors as a crucial determinant of their success - and longevity. For example, Alesina and Perotti (1995) and Perroti et al. (1998) have argued that fiscal adjustments that rely too heavily on increasing tax revenue rather than on cutting government spending are less likely to be successful and sustainable. This has recently been challenged by Tsibouris et al (2006), who show that tax-based consolidations can also succeed in countries where the initial tax to GDP ratio is low and where policy changes are implemented gradually (i.e., frontloading should be avoided).
} 
variables required for our investigation. Section 4 explains the main econometric specification and data used for our investigation, and in Section 5 we present the results of our econometric testing which show that the higher is the reliance on tax-based relative to spending-based budget consolidation the higher will be the decline in output per unit of improvement in the current account balance. Extensive robustness tests are carried in Section 6, which confirm the empirical relevance of our main hypothesis. Concluding remarks are offered in Section 7.

\section{Theoretical Considerations}

Since Frenkel and Razin's (1992) comprehensive analysis of the effects of government spending and tax policies on key macroeconomic aggregates, it is well known that the influence of the government budget on the current account, depends, inter alia, on how (various) taxes and government spending are combined in order to generate a particular budget outcome. To some extent, the features which we wish to highlight in this paper elaborate further on the importance of the modality of budget outcomes for current account adjustment.

One such feature is the existence of differential rates of tax evasion between the traded and non-traded sectors. In most countries, the non-traded sector is dominated by services producers, many of which are self-employed or employ one or two employees (medical and law services, car repairs, haircuts, restaurants, etc.). That tax evasion is higher among the selfemployed than amongst employees is a sensible assumption to make for all countries irrespective of how efficient is their tax administration. Indeed, the literature for countries with efficient tax administrations (e.g. Denmark, Sweden, UK, USA) supports the idea that the selfemployed - who are mainly operating in the non-traded sector - evade more on their taxes than employees. For example, Kleven et al (2011), on the basis of a randomized tax enforcement experiment in Denmark involving more than 40,000 individual income tax filers and comprehensive administrative tax data found that the tax evasion rate is very small $(0.3 \%)$ for income subject to third-party reporting (i.e. employees) but substantial (37\%) for self-reported income. Engstrom and Holmlund (2009) use income and expenditure data to examine the extent of underreporting of income among self-employed individuals in Sweden, and conclude that households with at least one self-employed member underreport their total incomes by around 30 percent. ${ }^{5}$ Pissarides and Weber (1989) compared the relationship between food

\footnotetext{
${ }^{5}$ Moreover, they find that under-reporting of income appears to be twice as prevalent among self-employed people with unincorporated businesses as among those with incorporated businesses.
} 
expenditure and income in two groups of workers, self-employed and employees in employment, assuming that employees reported income correctly. Pissarides and Weber concluded that the self-employed had actual incomes which were equal 1.55 times their reported income, implying that the self-employed under-reported their actual income by about 33 percent. Finally, using US tax audit data Slemrod and Yitzhaki (2002) calculated that the rate of under-reporting of income from dependent employment was less than 1 percent, whereas the rate at which the self-employed under-reported their income was close to 58 percent. For countries with less efficient tax administration (e.g. Greece), the available evidence (e.g. Artavanis et al., 2012 ; Pappadà and Zylberberg , 2015) reaches the same conclusion, i.e. that tax evasion among the self-employed is much higher than for those subject to third-party reporting.

In addition, it is well known (e.g. de Paula and Scheinkman, 2009), that exporting firms usually transact with other formal-sector firms, like financial intermediaries, and also need the appropriate documentation to export. In contrast, non-traded sector firms usually use too little capital and do not engage in trans-border activities, they rely excessively on cash transactions, thereby avoiding the use of the financial sector. This makes it easier for them to avoid paying taxes as cash transactions leave no paper trail; in contrast, when firms make use of the financial sector, the tax authorities can gain access to their bank records and use this information to enforce the tax law. Eschewing the services provided by the financial sector is more costly for firms engaging in international transactions, thus their ability to evade taxes is smaller than non-traded sector producers. ${ }^{6}$

The implication of the above is that the effective after-tax relative price of the traded sector is smaller than what one would surmise by looking simply at the prices of the two sectors, thus attracting fewer resources in the traded sector. It also implies that a given reduction in domestic demand will have a different effect on the current account depending on whether it is achieved through a rise in tax rates or decreases in government spending. This is because, unlike a cut in government spending, a rise in the statutory tax rate(s) - for given rates of tax evasion in the two sectors - increases the relative attractiveness of the non-traded sector, decreases the production of traded goods and, for a given reduction in domestic absorption, generates a smaller improvement in the current account. As a result, in order to achieve a desired

\footnotetext{
${ }^{6}$ For some countries, tax evasion will be obviously more prevalent in the traded sector. One such example is the case of countries producing and exporting narcotics.
} 
improvement in the current account, the reduction in domestic absorption (i.e. the dose of fiscal consolidation) must be larger if based on tax increases, thus the output cost per unit of current account improvement (i.e. the sacrifice ratio) will be larger than if based on government spending decreases.

In what follows we assume that there is no tax evasion in the traded sector. (This is an innocuous assumption since the argument goes through as long the incidence of tax evasion is relatively larger in the non-traded sector.) Assuming that the economy we examine is small, the traded good's price is exogenous. ${ }^{7}$ We use the traded good as the numeraire. Let $v(0<v<1)$ denote the proportion of value added (or, more generally, of any taxable measure) that is detected by the tax authorities in the non-traded sector. Parameter $v$ thus provides also a measure of the differential rate of tax evasion between the two sectors, with a rise in $v$ implying a reduction in the difference in the rate of tax evasion between the two sectors, i.e. if $v=1$ there is no difference between the two sectors regarding tax evasion. Then, if $P$ is the price of the non-traded good, and $t$ is the (statutory) tax rate which applies in both sectors, the effective, after-tax, relative price of the non-traded good $(R P)$ faced by producers is,

$$
R P=P(1-v t) /(1-t)
$$

Equation (1) makes clear that the lower is $v$ (i.e. the higher is the effective tax differential between the two sectors) the higher will be $R P$.

Differentiating equation (1) with respect to the tax rate we find that,

$$
\frac{\partial(R P)}{\partial t}=\frac{P(1-v)}{(1-t)^{2}}>0
$$

Thus, as long as there are differences in the rates of tax evasion across sectors $(v<1)$, a rise in the tax rate increases the effective, after-tax, relative price of the non-traded good.

\footnotetext{
${ }^{7}$ This model is also known as the dependent economy model. It assumes a small economy which is a price taker in the world market of both importable and exportable goods. As a result, the country's (external) terms of trade are exogenously given and importables and exportables can be aggregated into a composite commodity - the traded good. Obstfeld and Rogoff (1996) provide a detailed presentation of the model.
} 
In order to illustrate the consequences of differential rates of tax evasion, we refer to Figure 1. The output of tradables is measured on the vertical axis, and that of the non-tradables on the horizontal axis. The initial production point is at point $Q$, where an effective relative price (denoted by $R P_{0}$ ) for the producers is tangent to the production possibilities frontier (PPF). Consumption is at point $D$, where an indifference curve (not shown) is tangent to the absorption $^{8}$ line $A_{0}$. The position of the absorption line measures the level of domestic spending, whereas its slope reflects the relative price faced by consumers. ${ }^{9}$ Market clearing for the non-traded goods under full employment of resources (i.e. internal balance) implies that their consumption will have to be equal to their production, so point $D$ lies vertically above point Q. Since the consumption of the traded good is larger than its domestic production, distance $Q D$ measures the initial trade deficit, which is facilitated by borrowing from abroad. In order to make our case as transparent as possible we assume that the current account deficit is due only to a government budget deficit (i.e. the private sector spends as much as it earns). To further simplify the diagram, we assume that the government returns in a lump-sum fashion to the private sector all tax revenue (so that the private sector's consumption point $\mathrm{C}$ is on the $\mathrm{PPF}$ ), and that the government demands the two goods in the same proportion as the private sector, i.e. the government spends $\mathrm{CH}$ on non-tradables and $\mathrm{HD}$ on tradables -in effect, we assume that the government demands the two goods in the same proportion as the private sector, since point $D$ is on the extension of the line $O C$ (the income-consumption line).

Figure 1: The Modality of Budget Consolidation and the Sacrifice Ratio

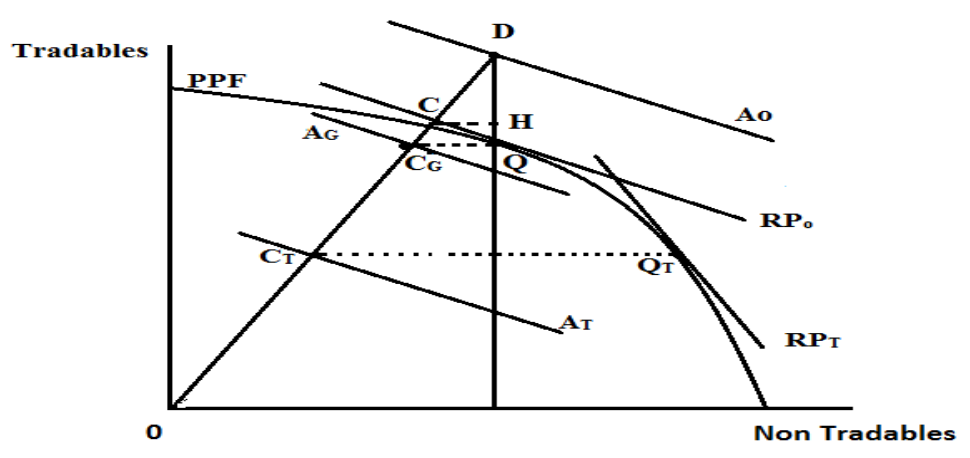

\footnotetext{
${ }^{8}$ As usual, the absorption is equal to domestic spending, with the difference between absorption and income being the external balance.

${ }^{9}$ The relative price faced by consumers will differ from that faced by producers due to the presence of tax evasion.
} 
Consider now that the domestic government engages in contractionary fiscal policy aiming at eliminating the external deficit. Assuming that wages and the price of non-tradables is sticky otherwise there would be no output costs, to achieve external balance requires cutting the level of absorption to the level depicted by line $A_{G}$ - so that domestic consumption of tradables at point $C_{G}$ is equal to domestic production. This would however involve a reduction in demand for non-tradables, reduction in output, and thus unemployment since the production point (at $C_{G}$ ) is inside the PPF. ${ }^{10}$

Alternatively, the government could reduce domestic absorption and eliminate the trade deficit by increasing taxes. With differential rates of tax evasion across sectors, the increase in the tax rate would cause a rise in the effective, after-tax, relative price of the non-traded sector that producers face, resources would be attracted away from the production of traded goods, and, if full employment prevailed, production would shift to point $Q_{T}$. To ensure that external balance is achieved, absorption would have to be cut to the level shown by line $A_{T}$, so that domestic consumption of tradables at point $C_{T}$ is equal to domestic production. This would again necessitate a dose of fiscal consolidation which involves a reduction in the demand for nontradables, reduction in output, and thus unemployment since the production point (at $C_{T}$ ) is inside the PPF.

Comparing the two cases it is clear that the contraction in output is larger if tax increases are used in order to eliminate the external deficit. Accordingly, the sacrifice ratio - defined as the drop in output per unit of improvement of the external deficit - is larger if taxes are raised than if government spending is cut; a corollary of this is that the higher is the reliance on tax increases than on government spending decreases, the higher will be the output costs of any given reduction in the external deficit.

\section{Current account adjustment episodes and measurement of the sacrifice ratio}

In this section we present our method for identifying current account adjustment episodes as well as the method we use to derive a measurement of the output cost of current account adjustments. We examine data for all countries in the IMF's World Economic Outlook during the 1980-2011 period, except for transition countries, oil-exporting countries, and microstates.

\footnotetext{
${ }^{10}$ Brecher (1974) provides an early diagrammatic analysis of how the existence of wage rigidity generates unemployment in Heckscher-Ohlin trade models. Other applications of wage rigidity using the PPF apparatus include Krugman (1995) and Davis (1998).
} 
Microstates are defined as countries with a population of less than 2 million (see, Endegnanew et al., 2012), and their current account balances display large variations which are not mainly related to changes in economic policy but to the external environment. This is also true for the oil-exporting countries; such economies generally run large current account surpluses and accumulate foreign assets during the extractive stage in order to smooth consumption once the non-renewable resources have been exhausted. For these economies the evolution of the current account - in addition to being affected by oil prices - may be affected by intended fluctuations in their production in order to stabilize the global oil market rather than any particular concern on their external position (IMF, 2013). We also exclude the transition countries from our study since the collapse of output during the early stages of transition was very large and co-existed with major structural change requiring large current account deficits which were financed by official international assistance and borrowing.

The methods we use have some similarity, but are not identical, to the ones used in the previous literature on current account adjustments and disinflation episodes. The first step is to identify adjustment episodes, i.e. periods where there is significant adjustment in the current account balance. Following on the influential study by Milesi-Ferretti and Razin (1998), current account adjustments have been chosen on the basis of criteria identifying, inter alia, the initial current account balance, the size of the adjustment, and its persistence. Thus, the subsequent literature (e.g. Freund (2005), Croke, Kamin, and Leduc (2005), Freund and Warnock (2007), Debelle and Galati (2007), Adalet and Eichengreen (2007), Algieri and Bracke (2011)) has followed the same general methodology, but has relaxed some of the earlier criteria in order to maximize the number of identified episodes. We adopt a similar strategy in the present paper, and we identify an adjustment episode when all of the following conditions are satisfied (variations of these conditions are also examined):

(i) the current account deficit (CAD) is at the start of the adjustment above 4 percent of GDP

(ii) it drops continuously by at least 2 percentage points of GDP, and remains below 3.5 percent of GDP for at least three years

(iii) there is no adjustment episode in the 3 years before the reversal starts.

We consider the start of the adjustment period to be when the current account deficit as percentage of GDP is at its peak (and above 4 percent), and the end of the adjustment period to 
take place either after two consecutive years of current account surpluses, or after three consecutive years of current account deficits lower than 3.5 percent of GDP.

An important step in our empirical strategy relates to the calculation of the sacrifice ratio. The denominator of the sacrifice ratio is the change in the current account balance (percentage points of GDP) from the beginning of the adjustment period to its end. The numerator of the sacrifice ratio is the cumulative output loss - i.e. the sum of differences between trend output and actual output during the period of adjustment. To calculate the trend output series we use a variant of the method followed by Ball (1994). ${ }^{11}$ Ball's method of determining trend output in his study of disinflation episodes, was to connect output at the start of the disinflation episode (i.e. when inflation was at its peak), to output one year after the trough in inflation. To apply the same method in our case would involve connecting output at the start of the current account adjustment episode to output one year after the end of the adjustment. Although Ball's method may be a reasonable approximation for disinflation episodes ${ }^{12}$, we demonstrate in Figure 2 that a better approximation to trend output can be used.

Figure 2: An Illustration of the Trend Line and the SR
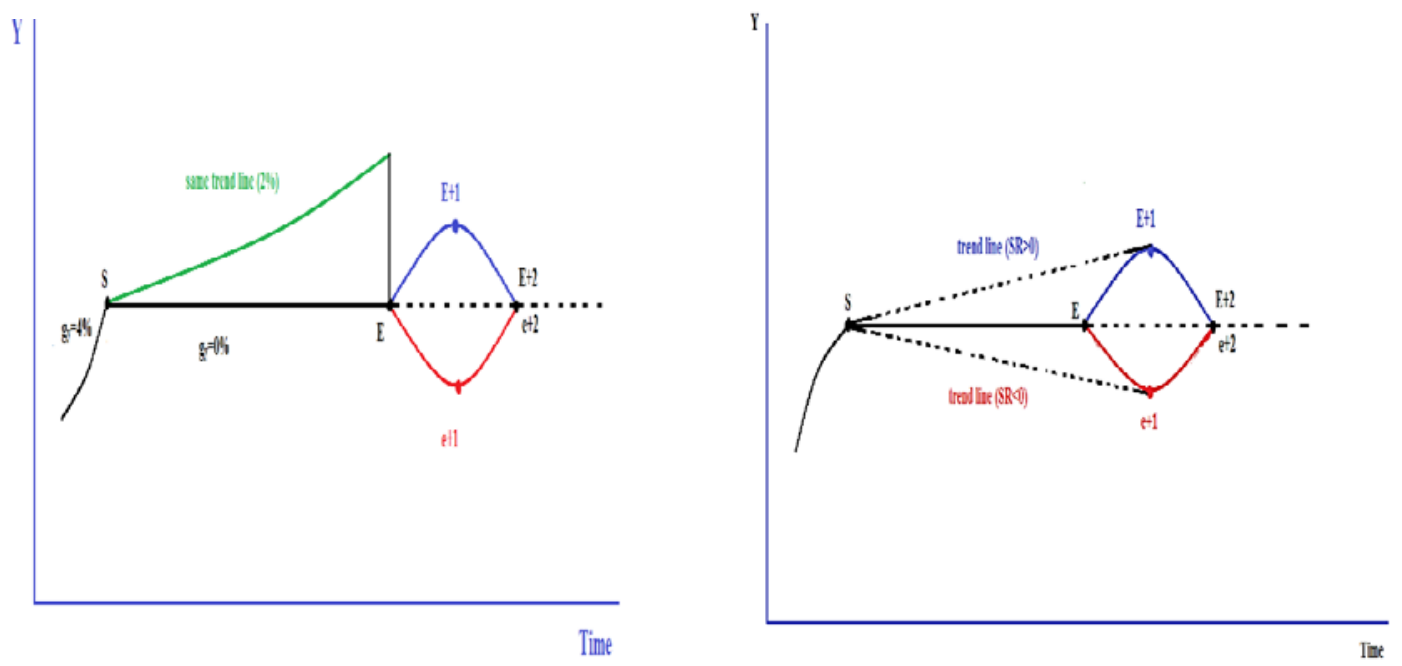

\footnotetext{
${ }^{11}$ Another approach to calculate the output cost - used in the disinflation literature - is to estimate a Phillips curve (Okun, 1978; Gordon and King, 1982). A limitation of this approach is that it constrains the output-inflation trade-off to be the same during disinflations as during increases in trend inflation or temporary fluctuations in demand. As argued by Ball (1994), this restriction fails if the sacrifice ratio is influenced by factors specific to disinflations, such as incomes policies or credibility-induced shifts in expectations. Most important, the Phillipscurve approach constrains the sacrifice ratio to be the same for all disinflations within a time series. The procedure followed in this paper allows the calculation of different sacrifice for each adjustment episode. ${ }^{12}$ This is because the change in inflation is zero at a peak, and the natural level of output in (closed-economy) macroeconomics is often defined as the level consistent with stable inflation.
} 
In Figure 2a we demonstrate how much a direct application of Ball's methodology to estimating trend output depends on what happens to output one year after the end of adjustment. At the start of adjustment (denoted by point $S$ ), the output path (the solid line) becomes flat until the end of adjustment (denoted by point E). The year after the end of adjustment, output could either rise to point E+1 (and then follow the path following from point $\mathrm{E}+2$ onwards), or it could drop to $\mathrm{e}+1$ (and then follow the path following from point e+2 onwards). Barring any other information, the upper output path is preferable to the lower output path. Yet, the trend output line for the upper path would be the (broken) line connecting points $S$ and $E+1$, which lies above the actual output path, implying a positive sacrifice ratio (SR); in contrast, the trend output line for the lower path is below the actual output path in this case, implying a negative SR (i.e. that output during the adjustment was higher than "trend" output). This undesirable feature of the method of calculating trend output is clearly due to relying too much on how output evolves just one year after the end of adjustment. To correct for this, we use a different method, which is illustrated in Figure 2b. Our method admits that output growth before the start of the adjustment may have been unsustainable (e.g. due to excessive credit creation), and aims to find the trend output path by averaging ${ }^{13}$ between average output growth two years before the adjustment begins and two years after it ends. Thus, if average growth two years before the start of adjustment is 4 percent and average growth two years after the end of the adjustment is 0 , the trend output line between $\mathrm{S}$ and $\mathrm{E}$ would involve a growth rate of 2 percent, and would be (largely) independent of whether the zero (average) growth path two years after the adjustment is the upper or the lower path shown in Figure 2b. As a result, the SR would be (almost) the same for both output paths.

As an illustration of the differences in the SRs resulting from an application of the two methods, we have calculated them for the 82 adjustment episodes we have identified. Using Ball's (1994) methodology to calculate the SR produces a large number of negative SRs (i.e. current account adjustments generate output gains), sometimes as high as -33 (i.e. the cumulative rise in output above its trend is 33 times larger than the percentage point improvement in the current account balance). Given the empirical evidence cited earlier that current account adjustments are more likely to be associated with output costs than output gains, we proceed in our investigation using this paper's method of calculating SRs.

\footnotetext{
${ }^{13}$ Obviously, output growth before the start of the adjustment may have been sustainable; for example, the occurrence of a large current account deficit could be the result of a rise in the world interest rate, resulting in higher debt service. We present robustness checks for different weighting schemes.
} 
Table 1: Calculated Sacrifice Ratios

\begin{tabular}{|lcl|}
\hline & Ball (1994) & This Paper \\
\hline Average Value of SR & -0.35 & 1.28 \\
\hline Number of SR $<0$ & 29 (of 82) & $3($ of 82$)$ \\
\hline Minimum SR & -33.0 & -0.25 \\
\hline Maximum SR & 3.2 & 3.12 \\
\hline
\end{tabular}

Due to missing fiscal data for 32 of the adjustment episodes we have identified, our analysis is based on 50 episodes. These are presented in the Appendix, along with the calculated SR in each case. The largest current account deficit (among these episodes) at the beginning of the adjustment was 15.1 percent (of GDP), the smallest 4.1 percent, and the average current account deficit 6.7 percent. At the end of the adjustment, there was, on average, a current account surplus of 0.9 percent, whereas the largest surplus was 15.9 percent and the largest deficit was 3.4 percent. These figures imply that, on average, the improvement was equal to 7.6 percentage points (of GDP). This improvement was a result of an average increase in the exports to GDP ratio by 4.6 percentage points, and a decline in the imports to GDP ratio by 1.1 percentage points. The shortest adjustment episodes took two years to come to an end, the duration of the median episode was 3 years, and the longest episode was 7 years.

\section{Econometric Specification and Data}

Given our interest on how the modality of fiscal consolidation affects the SR of current account adjustments, we proceed now to specify our main econometric equation. As a first step, we construct the variable which measures the modality of budget consolidation. To do so, we estimate the variables Cyclically Adjusted Expenditure (\% of GDP) and Cyclically Adjusted Revenue (percent of GDP). We use the relevant cyclically adjusted variables since we are interested in the effect of deliberate fiscal policy responses. To this end we take the component of the Expenditure and Revenues (as percent of GDP) which are not explained by the growth rate of the economy or a time trend. These data are obtained from IMF's, World Economic Outlook. Then, the variable measuring the modality of the fiscal adjustment is defined as the ratio of the Change in Cyclically Adjusted Revenue (percent of GDP) to the Change in the Cyclically Adjusted Expenditure (percent of GDP) during the adjustment period. We denote this variable as Modality ${ }_{i, t}$, and we shall often refer to an increase in it as a "heavier reliance on tax increases". 
To control for various changes in domestic and international economic conditions affecting the SR of current account adjustments we use in our baseline specification the following variables: (i) The Change in the Real Effective Exchange Rate (DREER- taken from Darvas, 2012) controls for changes in the price competiveness vis-à-vis the rest of the world (e.g. a depreciation of the REER is expected to improve the external balance without requiring a large drop in domestic output).

(ii) In addition to $D R E E R$, we allow for the exchange rate regime per se to potentially affect the SR, since a given change in the real exchange rate may have different consequences depending on whether it is brought about through external (i.e. through nominal exchange rate adjustment) or internal (i.e. domestic wages and prices) devaluation. We thus use the variable Fixed $X R$, which takes the value of 1 if the country has a de-facto fixed exchange rate regime in the beginning of the adjustment. The data for this variable are taken from Levy- Yeyati and Sturzenegger (2003) - which is continuously updated.

(iii) Since it is possible to have a change in the exchange rate regime during an adjustment episode - which may disrupt the adjustment process, we control for this by using the variable Change in XR regime, which takes the value of 1 if there is a change in the de-facto exchange rate regime during the adjustment period (the relevant information is drawn from Levy- Yeyati and Sturzenegger, 2003).

(iv) The variable Length of Adjustment is introduced in order to control for the possible influence of rapid versus slow adjustments on the SR - possibly capturing political economy issues related to the so-called stabilization fatigue ${ }^{14}$ which can introduce uncertainty about the future course of the programme and the economy. This variable is measured as the simple count of the number of years over which the adjustment is completed.

(vi) The variable \% of adj in 1st year measures the share of current account change that takes place in the first year of the adjustment, and it is meant to capture whether frontloading the adjustment effort can influence the SR. ${ }^{15}$ Frontloading can either generate a sense of the eventual success of the programme - thus possibly increasing the political support for it since the adjustment period can be conceived as not being very protracted, or it may be associated with such a large output contraction that decreases political support for the programme and the enactment of the most effective policies - thus increasing the SR.

\footnotetext{
${ }^{14}$ The term stabilization fatigue was coined to describe the experience of Latin American countries with longlasting stabilization programmes.

${ }^{15}$ The data for this and the previous variable are derived by own calculations using the data on the SR as derived in the previous section.
} 
(vii) Exports at the beginning, defined as exports over GDP at the beginning of the adjustment period accounts for the ability of more export oriented economies to offset a larger part of the drop in aggregate demand due to fiscal consolidation through a boost in their exports, since a given percentage rise in exports will impact more on countries in which exports are a large percentage of GDP. The data for this variable are drawn from World Bank's (2015) World Development Indicators.

(viii) The variable Change I/R measures the change in the US Treasury10-year bond interest rate over the course of the adjustment, which is meant to proxy for the change in the world interest rate, and thus for the burden of servicing the country's external debt. The source of the data is World Bank (2015).

The model we estimate takes the form:

$$
\begin{aligned}
& S R_{i, t}=\beta_{1} \text { Modality }_{i, t}+\beta_{2} \text { Fixed_X } R_{i, t}+\beta_{3} \text { Change_XR_regime }_{i, t}+\beta_{4} \text { Length }_{i, t}+\beta_{5} \text { Exports }_{i, t}+ \\
& \beta_{6} \mathrm{DREER}_{i, t}+\beta_{7} i / r_{-} \text {change }{ }_{t}+\beta_{4} \% \text { _of _adj_1st_year } r_{i, t}+\beta_{0}+u_{i, t}
\end{aligned}
$$

where $u_{i, t}$ is the error term.

\section{Baseline Results}

The results are presented in Table 2. According to column (1), which does not include the main variable of interest (i.e. the relative reliance on tax revenue increases), the only variables that turn out to have a (statistically) significant effect on the SR are the change in the US Treasury10 year bond rate ( $\mathrm{i} / \mathrm{r}$ change) and the length of the adjustment episode (Length). They both turn out positive, suggesting that an increase in the world interest rate and adjustments that take more time to be completed result into higher output losses per unit of improvement in the current account (i.e. increase the SR). The rest of the variables turn out insignificant at all relevant levels of statistical significance. 


\begin{tabular}{|c|c|c|c|c|c|c|c|c|c|}
\hline & (1) & $(2)$ & (3) & $(4)$ & (5) & (6) & (7) & (8) & (9) \\
\hline & No policy & relative $p$ & I frontload & X\&M & trade defi & $\mathrm{i} G \& \mathrm{~T}$ & CA open & labour reg & democracy \\
\hline Fixed $X R$ & $\begin{array}{l}-0.150 \\
(-0.59)\end{array}$ & $\begin{array}{l}-0.336 \\
(-0.97)\end{array}$ & $\begin{array}{l}-0.264 \\
(-0.80)\end{array}$ & $\begin{array}{l}-0.249 \\
(-0.76)\end{array}$ & $\begin{array}{l}-0.253 \\
(-0.79)\end{array}$ & $\begin{array}{l}-0.199 \\
(-0.59)\end{array}$ & $\begin{array}{l}-0.322 \\
(-0.84)\end{array}$ & $\begin{array}{l}-0.245 \\
(-0.80)\end{array}$ & $\begin{array}{l}-0.347 \\
(-0.82)\end{array}$ \\
\hline Change in $X R$ regime & $\begin{array}{l}0.003 \\
(0.01)\end{array}$ & $\begin{array}{l}-0.267 \\
(-0.79)\end{array}$ & $\begin{array}{l}-0.348 \\
(-1.17)\end{array}$ & $\begin{array}{l}-0.335 \\
(-1.14)\end{array}$ & $\begin{array}{l}-0.350 \\
(-1.33)\end{array}$ & $\begin{array}{l}-0.240 \\
(-0.80)\end{array}$ & $\begin{array}{l}-0.318 \\
(-1.08)\end{array}$ & $\begin{array}{l}-0.310 \\
(-1.09)\end{array}$ & $\begin{array}{l}-0.330 \\
(-1.10)\end{array}$ \\
\hline Length of adj & $\begin{array}{l}0.346^{\star \star} \\
(2.57)\end{array}$ & $\begin{array}{l}0.357^{\star *} \\
(2.63)\end{array}$ & $\begin{array}{l}0.506^{\star \star \star} \\
(3.81)\end{array}$ & $\begin{array}{l}0.493^{\star \star \star} \\
(3.86)\end{array}$ & $\begin{array}{l}0.499 * \star \star \\
(4.25)\end{array}$ & $\begin{array}{l}0.519^{\star \star \star \star} \\
(3.59)\end{array}$ & $\begin{array}{l}0.502^{\star \star \star} \\
(3.88)\end{array}$ & $\begin{array}{l}0.509 * \star \star \\
(3.96)\end{array}$ & $\begin{array}{l}0.509^{\star \star \star} \\
(3.65)\end{array}$ \\
\hline DREER & $\begin{array}{l}-0.005 \\
(-1.40)\end{array}$ & $\begin{array}{l}-0.002 \\
(-0.51)\end{array}$ & $\begin{array}{l}-0.005 \\
(-1.20)\end{array}$ & $\begin{array}{l}-0.004 \\
(-0.98)\end{array}$ & $\begin{array}{l}-0.005 \\
(-1.24)\end{array}$ & $\begin{array}{l}-0.003 \\
(-0.64)\end{array}$ & $\begin{array}{l}-0.005 \\
(-1.16)\end{array}$ & & $\begin{array}{l}-0.006 \\
(-1.12)\end{array}$ \\
\hline$X$ at beginning & $\begin{array}{l}-0.001 \\
(-0.23)\end{array}$ & $\begin{array}{l}0.000 \\
(0.00)\end{array}$ & $\begin{array}{l}-0.000 \\
(-0.01)\end{array}$ & $\begin{array}{l}0.005 \\
(0.44)\end{array}$ & & $\begin{array}{l}-0.002 \\
(-0.36)\end{array}$ & $\begin{array}{l}0.000 \\
(0.02)\end{array}$ & $\begin{array}{l}0.001 \\
(0.11)\end{array}$ & $\begin{array}{l}-0.000 \\
(-0.07)\end{array}$ \\
\hline $\mathrm{i} / \mathrm{r}$ Change & $\begin{array}{l}0.166^{\star \star} \\
(2.31)\end{array}$ & $\begin{array}{l}0.236^{\star \star} \\
(2.11)\end{array}$ & $\begin{array}{l}0.242^{\star \star} \\
(2.66)\end{array}$ & $\begin{array}{l}0.228^{\star \star} \\
(2.53)\end{array}$ & $\begin{array}{l}0.233^{\star \star \star} \\
(2.79)\end{array}$ & $\begin{array}{l}0.184 \\
(1.54)\end{array}$ & $\begin{array}{l}0.247^{\star \star \star} \\
(2.73)\end{array}$ & $\begin{array}{l}0.253^{\star \star} \\
(2.56)\end{array}$ & $\begin{array}{l}0.229 \star \star \\
(2.44)\end{array}$ \\
\hline Modality & & $\begin{array}{l}0.090^{\star \star \star} \\
(2.93)\end{array}$ & $\begin{array}{l}0.082^{\star \star \star} \\
(3.87)\end{array}$ & $\begin{array}{l}0.082^{\star \star \star} \\
(4.12)\end{array}$ & $\begin{array}{l}0.082^{\star \star \star} \\
(4.12)\end{array}$ & $\begin{array}{l}0.077^{\star \star \star *} \\
(3.07)\end{array}$ & $\begin{array}{l}0.082^{\star \star \star} \\
(3.73)\end{array}$ & $\begin{array}{l}0.084^{\star \star \star} \\
(3.90)\end{array}$ & $\begin{array}{l}0.080^{\star \star \star} \\
(3.23)\end{array}$ \\
\hline$\%$ of adj in 1st year & & & $\begin{array}{l}0.700^{\star \star \star *} \\
(2.70)\end{array}$ & $\begin{array}{l}0.698^{\star \star} \\
(2.59)\end{array}$ & $\begin{array}{l}0.698^{\star *} \\
(2.65)\end{array}$ & $\begin{array}{l}0.680^{\star *} \\
(2.53)\end{array}$ & $\begin{array}{l}0.688^{\star \star} \\
(2.53)\end{array}$ & $\begin{array}{l}0.654^{\star \star} \\
(2.36)\end{array}$ & $\begin{array}{l}0.700^{\star \star} \\
(2.47)\end{array}$ \\
\hline$M$ at beginning & & & & $\begin{array}{l}-0.006 \\
(-0.49)\end{array}$ & & & & & \\
\hline Trade deficit & & & & & $\begin{array}{l}-0.005 \\
(-0.48)\end{array}$ & & & & \\
\hline Change in Revenue & & & & & & $\begin{array}{l}-0.017 \\
(-1.10)\end{array}$ & & & \\
\hline Change in Spending & & & & & & $\begin{array}{l}0.001 \\
(0.10)\end{array}$ & & & \\
\hline CA openness & & & & & & & $\begin{array}{l}-0.141 \\
(-0.33)\end{array}$ & & \\
\hline Labor Regulation & & & & & & & & $\begin{array}{l}-0.006 \\
(-0.80)\end{array}$ & \\
\hline Democracy beginning & & & & & & & & & $\begin{array}{l}-0.012 \\
(-0.39)\end{array}$ \\
\hline Change in Democracy & & & & & & & & & $\begin{array}{l}-0.013 \\
(-0.29)\end{array}$ \\
\hline Constant & $\begin{array}{l}0.393 \\
(0.87)\end{array}$ & $\begin{array}{l}0.500 \\
(1.10)\end{array}$ & $\begin{array}{l}-0.486 \\
(-0.86)\end{array}$ & $\begin{array}{l}-0.381 \\
(-0.67)\end{array}$ & $\begin{array}{l}-0.431 \\
(-0.91)\end{array}$ & $\begin{array}{l}-0.461 \\
(-0.79)\end{array}$ & $\begin{array}{l}-0.410 \\
(-0.71)\end{array}$ & $\begin{array}{l}-0.101 \\
(-0.14)\end{array}$ & $\begin{array}{l}-0.449 \\
(-0.76)\end{array}$ \\
\hline obs & 82 & 50 & 50 & 50 & 50 & 50 & 49 & 50 & 50 \\
\hline F-test & 1.60 & 4.07 & 7.65 & 8.57 & 9.39 & 4.89 & 6.90 & 7.56 & 5.08 \\
\hline $\mathrm{R} 2$ & 0.10 & 0.17 & 0.31 & 0.31 & 0.31 & 0.33 & 0.31 & 0.31 & 0.31 \\
\hline
\end{tabular}

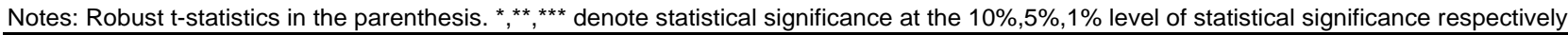

In column (2) we introduce the main variable of interest, which turns out positive and statistically significant at the $1 \%$ level. This suggests that the modality of budget consolidation crucially affects the output costs of current account adjustments, with those relying more on revenue increases resulting into a higher SR. Quantitatively our results suggest that an adjustment which is based equally on changes in tax increases and spending decreases is expected to have 0.09 lower SR that a budget adjustment which relies two-thirds on revenue increases and one-third on spending decreases. Note also that the introduction of this variable does not impact on the significance of the rest of the variables, even though our sample decreases relative to the one in column (1). The decrease in the number of adjustment episodes considered is due to the fact that the variable measuring the modality of fiscal consolidation cannot be constructed for some adjustment episodes, as the fiscal data for many countries on IMF’s World Economic Outlook are not available before 1990. 
The results in column (2) are suggestive in another respect: as the variable Length is positive and statistically significant, we can conclude that shorter adjustment episodes typically come with a lower SR. To explore further this idea, in column (3) we introduce the variable \% of adj in $1^{\text {st }}$ year, which measures the percentage change in the current account balance that is achieved in the first year of the adjustment episode. According to column (3), this variable is positive and significant, suggesting that frontloaded current account adjustments are associated with higher output losses. At first sight this may seem paradoxical since one may assume that the more frontloaded is the adjustment, the shorter will be the length of the adjustment episode. However, there is no necessary (positive) relationship between frontloading and adjustment length. For example, a two-year adjustment episode can be achieved through either an $80 \%$ adjustment in the current account balance in the first year and 20\% in the second year (frontloaded adjustment), or through $20 \%$ in the first and $80 \%$ in the second. What our results indicate is that the "policy prescription" should be "keep your adjustment period short, but don't frontload it". 16

Columns (1) and (2) suggest that neither the exchange rate regime nor changes in the real effective exchange rate have any influence on the $S R$. These results do not necessarily indicate that either the exchange rate regime, or changes in the real exchange rate have no influence on the current account balance - they just indicate that they do not affect the output costs per unit of current account adjustment. In any case, we note that, in principle, we would expect relative price effects to be more relevant for variations in the trade balance rather than the current account. Moreover, and despite the widespread belief that the behaviour of real exchange rates is an important determinant of either the current account or the trade balance, the post-1980s empirical literature has failed to provide ample support that this is indeed the case (see, e.g. Rose, 1991; Chinn and Prasad, 2003). ${ }^{17}$

In the rest of the columns of Table 2, we introduce a series of variables that may be associated with the SR. Specifically we introduce: (i) the share of imports to GDP ratio at the beginning of the adjustment ( $M$ at the beginning, column (4)) as a way to capture the differential ability of countries to substitute domestic production for imports; (ii) the trade deficit at the beginning

\footnotetext{
${ }^{16}$ Moreover, the adjustment is not for all episodes monotonic (i.e. there is not always a gradual improvement in the current account balance); an "overshooting" of current account adjustment in the first year may be associated with a large recession which results into a higher SR.

${ }^{17}$ A possible explanation for this is the recent rise in the degree of vertical specialisation and the spread of global supply chains which tends to offset the presumed cost competitiveness benefits of exchange rate changes in the case of inter-firm linkages in the sourcing of intermediate inputs.
} 
of the adjustment (as \% of GDP- column (5)) as a way to capture the size of income declines needed to close the trade gap; (iii) the Fernandez et al. (2015) index of capital account openness (column (6)), to capture the possibility that greater capital account openness makes an economy more susceptible to negative financing shocks, which may require sharp output declines during current account reversals which may not be driven by domestic policy developments; (iv) the Heritage index of labour market regulation (column (7)) as a way to capture the ability of the economy to adjust to negative aggregate demand shocks and to the reallocation of economic activity from the non-traded to the traded sector; and (v) the POLITY IV index of democracy (column (8)), since political institutions may influence the ability of the government to enact a host of other reforms (e.g. structural reforms) which can influence the SR. The results of columns (4)-(8) indicate that none of these variables turn out to exert a statistically significant influence on the SR. We note that the variable measuring the modality of fiscal consolidation remains significant in all cases Moreover, the introduction of these variables has no effect on the rest of the variables appearing in column (3) - the only exception being regarding the influence of the world interest rate in column (6). With the above in mind we consider column (3) to be our main specification and in the tables that follow we perform the robustness analysis according to this specification.

\section{Robustness Analysis}

To examine the robustness of our results to the specification employed, in Table 3 we reestimate our main model distinguishing further between exchange rate regimes. Starting with column (1), instead of using only a dummy variable for countries classified under a de-facto fixed exchange rate regime, we use separate dummy variables for the de facto- floating and the intermediate exchange rate regimes (Levy-Yeyati and Sturzenegger, 2003). Our initial results remain robust in this specification as well. In column (2) we return to our baseline model, but we now allow for the coefficient of $X$ at Beginning variable to vary between fixed and nonfixed exchange rate regimes. We do so since the output losses suffered from an internal devaluation (i.e. under fixed exchange rates) may depend more on the initial exports to GDP ratio than under a flexible exchange rate regime. As the reader can readily verify the effect of $X$ 


\begin{tabular}{|c|c|c|c|c|c|c|c|c|}
\hline & (1) & (2) & (3) & (4) & (5) & (6) & (7) & (8) \\
\hline & All $X R$ & interaction & & & & Growth(80 & Growth $(70$ & Growth(60 \\
\hline & types & $x$ & Same XR & not fixed & only Fixed & $\%-20 \%)$ & $\%-30 \%)$ & $\%-40 \%)$ \\
\hline \multirow[t]{2}{*}{ Intermediate XR } & 0.432 & & & & & & & \\
\hline & (0.89) & & & & & & & \\
\hline \multirow[t]{2}{*}{ Floating XR } & 0.269 & & & & & & & \\
\hline & $(0.77)$ & & & & & & & \\
\hline \multirow[t]{2}{*}{ Change in $\mathrm{XR}$ regime } & -0.356 & -0.337 & & -0.304 & $-1.980 *$ & -0.277 & -0.301 & -0.324 \\
\hline & $(-1.02)$ & $(-1.15)$ & & $(-0.98)$ & $(-3.41)$ & $(-0.96)$ & $(-1.08)$ & $(-1.15)$ \\
\hline \multirow[t]{2}{*}{$X$ at beginning } & 0.002 & 0.001 & -0.000 & 0.001 & -0.014 & -0.005 & -0.004 & -0.002 \\
\hline & $(0.32)$ & $(0.16)$ & $-0.00)$ & $(0.14)$ & $(-0.77)$ & $(-0.94)$ & $(-0.65)$ & $(-0.33)$ \\
\hline \multirow[t]{2}{*}{ Modality } & $0.081^{\star \star *}$ & $0.083^{\star \star \star}$ & $0.075^{\star \star \star}$ & $0.075^{\star \star \star}$ & $0.912^{*}$ & $0.072^{\star \star \star}$ & $0.075^{\star \star \star}$ & $0.079 * \star \star$ \\
\hline & (3.51) & $(3.72)$ & $(3.26)$ & $(4.04)$ & (3.19) & $(3.30)$ & $(3.56)$ & $(3.75)$ \\
\hline \multirow[t]{2}{*}{ DREER } & -0.006 & -0.005 & -0.011 & -0.009 & -0.001 & $-0.008^{*}$ & $-0.007^{*}$ & -0.006 \\
\hline & $(-1.27)$ & $(-1.03)$ & $-0.94)$ & $(-1.01)$ & $(-0.11)$ & $(-1.91)$ & $(-1.73)$ & $(-1.48)$ \\
\hline \multirow[t]{2}{*}{ Length of adj } & $0.505^{\star \star *}$ & $0.504^{\star \star *}$ & $0.640^{* * *}$ & $0.518^{\star * *}$ & -1.304 & $0.473^{\star \star *}$ & $0.484^{\star \star *}$ & $0.495^{\star \star *}$ \\
\hline & $(3.59)$ & $(3.70)$ & $(2.79)$ & $(3.29)$ & $(-2.21)$ & (3.58) & $(3.74)$ & (3.82) \\
\hline \multirow[t]{2}{*}{$\%$ of adj in 1 st year } & $0.635^{\star \star}$ & $0.695^{\star \star}$ & 0.435 & 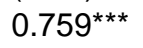 & $-3.669^{\star}$ & $0.588^{\star \star}$ & $0.626^{\star \star \star}$ & $0.663^{\star \star \star}$ \\
\hline & $(2.28)$ & $(2.66)$ & $(1.04)$ & $(2.94)$ & $(-3.44)$ & $(2.56)$ & $(2.77)$ & $(2.80)$ \\
\hline \multirow[t]{2}{*}{ i/r Change } & $0.238^{\star \star}$ & $0.241^{\star \star}$ & $0.339 * \star \star$ & $0.222^{\star \star}$ & $-1.325^{\star \star}$ & $0.222^{\star \star}$ & $0.229 \star \star$ & $0.235^{\star \star}$ \\
\hline & $(2.43)$ & $(2.60)$ & $(2.90)$ & $(2.26)$ & $(-5.06)$ & $(2.22)$ & $(2.45)$ & $(2.60)$ \\
\hline \multirow[t]{2}{*}{ Fixed XR } & & -0.098 & -0.085 & & & -0.476 & -0.405 & -0.334 \\
\hline & & $(-0.17)$ & $(-0.17)$ & & & $(-1.29)$ & $(-1.22)$ & $(-1.05)$ \\
\hline \multirow[t]{2}{*}{$X$ at beginning ${ }^{\star}$ Fixed $X R$} & & -0.005 & & & & & & \\
\hline & & $(-0.47)$ & & & & & & \\
\hline \multirow[t]{2}{*}{ Constant } & -0.783 & -0.511 & -0.650 & -0.646 & $8.068^{*}$ & -0.279 & -0.348 & -0.417 \\
\hline & $(-1.18)$ & $(-0.89)$ & $-0.75)$ & $(-1.04)$ & (3.22) & $(-0.51)$ & $(-0.63)$ & $(-0.75)$ \\
\hline obs & 50 & 50 & 33 & 40 & 10 & 50 & 50 & 50 \\
\hline F-test & 6.39 & 5.96 & 5.32 & 9.09 & 19.76 & 7.24 & 7.79 & 7.94 \\
\hline R2 & 0.30 & 0.31 & 0.26 & 0.34 & 0.83 & 0.29 & 0.30 & 0.31 \\
\hline
\end{tabular}

at Beginning remains insignificant irrespective of the exchange rate regime. In column (3) we estimate our baseline equation only for the countries that do not change their exchange rate regime during the adjustment episode. A change in exchange rate regime may be, among other things, indicative of the co-existence of currency or banking crises during the adjustment episode, which are well-known to have large output costs (Dornbusch et al., 1995). Dropping the 17 adjustment episodes for which there was a change in the exchange rate regime, the sample size drops to 33 episodes, but still the modality of budget consolidation (as well as the length of adjustment, and the world interest rate) remains a significant influence on the SR. In columns (4) and (5) we split the sample according to the exchange regime. Therefore, instead of assuming that in a fixed exchange rate regime only the constant term changes, we assume that all the coefficients change. When the exchange rate regime is not classified as fixed, there are 40 adjustment episodes, and the previous results regarding our main variable of interest remain intact. When, in column (5), we consider only the episodes involving a fixed exchange 
rate regime we have only 10 cases, therefore the results in column (5) are derived using a very small sample and thus, although being the same as the previous cases, no confidence can be placed in the results of this column.

In columns (6) to (8) we examine the robustness of our conclusions to changes in the way we calculate the SR. This is essential since our decision to place equal weight on the (two-year) average growth rate before the beginning of adjustment and on the (two-year) average growth rate after the end of adjustment for calculating the trend output path during the adjustment period is obviously open to debate. For example, it could be argued that some current account adjustments follow on periods of unsustainable output growth fuelled by excessive credit expansions, thus placing equal weight on pre-adjustment growth is equivalent to giving undue weight to an unsustainable growth rate. Yet, other adjustment episodes are not associated with any significant (positive) difference between pre-adjustment and post-adjustment growth. To deal with this issue, we have decided to vary the weight placed on pre-adjustment growth rates. Thus, the results in column (6) are based on a SR which is derived from a trend output path that weighs the pre-adjustment, two-year growth average by $20 \%$ and the post-adjustment growth by $80 \%$. Similarly, in columns (7) and (8), the weights for calculating the trend output path, are set to $30 \%$ and $70 \%$ (pre- and post- adjustment) and $40 \%$ and $60 \%$, respectively. Again, the results in columns (6) to (8) remain the same irrespective of the weighting used to calculate the trend output path and the SR.

Additional robustness tests are provided in Table 4. An issue which is dealt with in many of the studies on current account adjustment cited in the Introduction, is the threshold initial current account deficit used for defining what constitutes an adjustment episode. In column (1) we assume that a current account adjustment begins when the current account deficit is above $4.5 \%$ (of GDP). This reduces the number of adjustment episodes by 9 (to 41), and it has no impact on the results, since the modality of budget consolidation, the length of adjustment, and the world interest rate retain their statistical significance, sign, and magnitude found in the previous Tables. In column (2), the threshold current account deficit is raised to above 5\%. This reduces the number of current account episodes to just 35, and still indicates that a heavier relative reliance on tax-based budget consolidation increases the SR (the coefficient is of similar size as in the previous regressions and remains significant at the $1 \%$ level of statistical significance). However, the other two variables that appeared to be significant determinants of 
the SR in the previous regressions (i.e. world interest rate, length of adjustment) are no longer statistically significant even at the $10 \%$ of statistical significance.

\begin{tabular}{|c|c|c|c|c|c|c|}
\hline & (1) & (2) & (3) & (4) & (5) & (6) \\
\hline & $c a<-4.5$ & $c a<-5$ & $\begin{array}{l}\text { median } \\
\text { regression }\end{array}$ & $\begin{array}{l}\text { interaction } \\
\text { length }\end{array}$ & $\begin{array}{l}\text { shadow } \\
\text { economy }\end{array}$ & $\begin{array}{l}\text { X/M mode } \\
\text { of adj }\end{array}$ \\
\hline Fixed XR & $\begin{array}{l}-0.256 \\
(-0.64)\end{array}$ & $\begin{array}{l}-0.102 \\
(-0.23)\end{array}$ & $\begin{array}{l}-0.372 \\
(-1.59)\end{array}$ & $\begin{array}{l}-0.225 \\
(-0.66)\end{array}$ & $\begin{array}{l}-0.268 \\
(-0.82)\end{array}$ & $\begin{array}{l}-0.252 \\
(-0.76)\end{array}$ \\
\hline Change in $\mathrm{XR}$ regime & $\begin{array}{l}-0.289 \\
(-0.87)\end{array}$ & $\begin{array}{l}-0.090 \\
(-0.30)\end{array}$ & $\begin{array}{l}-0.129 \\
(-0.43)\end{array}$ & $\begin{array}{l}-0.346 \\
(-1.16)\end{array}$ & $\begin{array}{l}-0.297 \\
(-0.96)\end{array}$ & $\begin{array}{l}-0.341 \\
(-1.28)\end{array}$ \\
\hline$X$ at beginning & $\begin{array}{l}0.001 \\
(0.18)\end{array}$ & $\begin{array}{l}-0.006 \\
(-1.07)\end{array}$ & $\begin{array}{l}0.000 \\
(0.03)\end{array}$ & $\begin{array}{l}0.001 \\
(0.09)\end{array}$ & $\begin{array}{l}-0.000 \\
(-0.04)\end{array}$ & \\
\hline Modality & $\begin{array}{l}0.083^{\star \star *} \\
(4.06)\end{array}$ & $\begin{array}{l}0.069 \text { *** } \\
(4.00)\end{array}$ & $\begin{array}{l}0.069 \text { *** } \\
(4.68)\end{array}$ & $\begin{array}{l}0.209 \\
(1.57)\end{array}$ & & $\begin{array}{l}0.083^{\star \star \star *} \\
(3.92)\end{array}$ \\
\hline DREER & $\begin{array}{l}-0.006 \\
(-0.57)\end{array}$ & $\begin{array}{l}0.013 \\
(1.36)\end{array}$ & $\begin{array}{l}-0.006^{\star} \\
(-1.72)\end{array}$ & $\begin{array}{l}-0.004 \\
(-0.99)\end{array}$ & $\begin{array}{l}-0.004 \\
(-0.91)\end{array}$ & $\begin{array}{l}-0.006 \\
(-1.21)\end{array}$ \\
\hline Length of adj & $\begin{array}{l}0.483^{\star \star *} \\
(3.18)\end{array}$ & $\begin{array}{l}0.158 \\
(0.69)\end{array}$ & $\begin{array}{l}0.518^{\star * *} \\
(4.16)\end{array}$ & $\begin{array}{l}0.528^{\star \star \star *} \\
(3.96)\end{array}$ & $\begin{array}{l}0.533^{\star * *} \\
(3.96)\end{array}$ & $\begin{array}{l}0.506^{\star \star *} \\
(4.09)\end{array}$ \\
\hline$\%$ of adj in 1st year & $\begin{array}{l}0.676^{\star \star} \\
(2.29)\end{array}$ & $\begin{array}{l}-0.137 \\
(-0.36)\end{array}$ & $\begin{array}{l}1.001^{\star \star *} \\
(6.65)\end{array}$ & $\begin{array}{l}0.689 * * \\
(2.63)\end{array}$ & $\begin{array}{l}0.677^{\star *} \\
(2.62)\end{array}$ & $\begin{array}{l}0.702^{\star \star \star} \\
(2.77)\end{array}$ \\
\hline $\mathrm{i} / \mathrm{r}$ Change & $\begin{array}{l}0.243^{\star *} \\
(2.49)\end{array}$ & $\begin{array}{l}0.118 \\
(0.92)\end{array}$ & $\begin{array}{l}0.177^{\star * *} \\
(3.25)\end{array}$ & $\begin{array}{l}0.238^{\star *} \\
(2.65)\end{array}$ & $\begin{array}{l}0.239 \text { ** } \\
(2.65)\end{array}$ & $\begin{array}{l}0.244^{\star \star \star} \\
(2.78)\end{array}$ \\
\hline Modality*Length & & & & $\begin{array}{l}-0.038 \\
(-1.02)\end{array}$ & & \\
\hline Modality*shadow economy & & & & & $\begin{array}{l}0.283^{\star \star \star} \\
(2.77)\end{array}$ & \\
\hline Change X/Change $\mathrm{M}$ & & & & & & $\begin{array}{l}-0.004 \\
(-0.34)\end{array}$ \\
\hline Constant & $\begin{array}{l}-0.488 \\
(-0.75)\end{array}$ & $\begin{array}{l}1.072 \\
(1.11)\end{array}$ & $\begin{array}{l}-1.016^{\star} \\
(-1.71)\end{array}$ & $\begin{array}{l}-0.556 \\
(-0.99)\end{array}$ & $\begin{array}{l}-0.563 \\
(-0.97)\end{array}$ & $\begin{array}{l}-0.492 \\
(-1.01)\end{array}$ \\
\hline obs & 41 & 35 & 50 & 501 & 48 & 50 \\
\hline F-test & 7.39 & 4.94 & & 8.55 & 7.26 & 7.42 \\
\hline R2 & 0.30 & 0.28 & & 0.32 & 0.31 & 0.31 \\
\hline
\end{tabular}

Notes: Robust t-statistics in the parenthesis. ${ }^{*},{ }^{* *}{ }^{* \star *}$ denote statistical significance at the $10 \%, 5 \%, 1 \%$ level of statistical significance respectively

We now proceed to examine the robustness of our results by checking whether they are driven by individual outliers. Since our sample consists of many heterogeneous countries, a potential source of worry may be the presence of outliers among the identified adjustment episodes. To deal with this, we employ robust regression analysis using the MM- estimator (Yohai, 1987). Following Rousseeuw and Yohai (1987), instead of minimizing the variance of the residuals (as the OLS does) this class of estimators minimizes measures of dispersion of the residuals that are less sensitive to outliers. The results shown in column (3) verify that our empirical findings so far remain highly resilient to robust regression techniques. 
The main argument of the paper regarding the effects of the modality of fiscal consolidation on the SR rests on the existence of differences in the rates of tax evasion between the traded and the non-traded sectors. Although there is no necessary direct link between the difference in the rates of tax evasion between the two sectors and the size of the shadow economy relative to officially measured GDP, it may be argued that the two variables are positively related. For example, the difference between countries with low and high administrative tax capability in the ability to collect taxes on employees in large firms is probably smaller than the difference in ability (between the two sets of countries) to collect taxes on the self-employed. To make this plain, it may be the case that the rates of tax evasion among employees are of similar magnitude in Denmark and Greece, but differ substantially when it comes to the taxation of the self-employed, with tax evasion among the self-employed being significantly higher in Greece than in Denmark (i.e. the country with an efficient tax administration). This implies that we may expect the influence of the modality of fiscal consolidation on the SR to be higher the higher is the overall rate of tax evasion in the economy. This is explored in column (4), where we control for the possible interaction between the modality variable (i.e. Change in T/Change in $G$ ) and our proxy for tax evasion; this proxy is share of the shadow economy as percentage of GDP, which we draw from Schneider et al. (2010). This interaction variable is not found to be statistically significant, although the modality of fiscal consolidation remains a significant determinant of the SR on its own.

Finally in column (5) we examine whether the SR is affected by the way trade flows adjust, i.e. whether most of the adjustment comes from a rise in exports or through a reduction in imports. It can be hypothesized that current account adjustments that are achieved through an increase in exports lead to lower output costs than those achieved through a reduction in imports since in the first case aggregate demand for domestically produced goods increases, whereas in the second case lower imports may just be a result of a contraction in economic activity. Although out results do not support this hypothesis, the modality of fiscal consolidation, the length of the adjustment episode, the frontloading of the current account correction, and the world interest rate still remain significant determinants of the SR.

\section{Conclusion}

The twin deficits hypothesis suggests that an improvement in a country's budget deficit will lead to an improvement in its current account balance. Leaving aside well-known theoretical 
and empirical objections about the validity of this hypothesis, we have argued that budget consolidations which rely heavily on tax revenue increases will be associated with larger output costs per unit of current account improvement than if they relied on government spending decreases. The empirical evidence presented in this paper supports this hypothesis.

To some extent our results indicate the potential importance of the supply side for current account adjustment. This is, of course, not new; after all, that the supply side, or, more generally, that a country's economic structure exercises large influence on how government policy affects the external balance has been well understood for a long time (e.g. Branson, 1983; Buiter, 1988). In this sense, our results about how differential rates of tax evasion interact with fiscal policy to affect the inter-sectoral allocation of economic activity and the current account provides yet another instance in which a country's economic structure interpreted in a broad way so as to include political and administrative constraints - is of fundamental importance for understanding why current account adjustments in non-industrial countries have been found to work through distinctly different channels than those in industrial countries (Milesi-Ferretti and Razin, 1998; Chinn and Prasad, 2003). This finding should be contrasted with our finding that neither the exchange rate regime nor changes in the real exchange rate affect the output costs of current account adjustments. 


\section{References}

Abbas, S.M. A., Bouhga-Hagbe, J., Fatás, A., Mauro, P. and Velloso, R. C. (2011). Fiscal Policy and the Current Account. International Monetary Fund, available at www.imf.org/external/np/seminars/eng/2010/eui/pdf/ABH.pdf.

Adalet, M. and B. Eichengreen (2007). Current Account Reversals: Always a Problem?, in R. H. Clarida (ed.), G7 Current Account Imbalances: Sustainability and Adjustment, pages 205-246 National Bureau of Economic Research, Inc.

Alesina, A. and Perotti R. (1995). Fiscal Expansions and Adjustments in OECD Economies. Economic Policy, 21, pp. 207-48.

Algieri, B. and T. Bracke (2011), Patterns of Current Account Adjustment. Insight from Past Experience, Open Economies Review 22, 401-425.

Artavanis, N.T., A. Morse, and M. Tsoutsoura, 2012, "Tax evasion Across Industries: Soft Credit Evidence from Greece”, Chicago Booth Research Paper No. 12-25.

Ball, L. (1994), "What Determines the Sacrifice Ratio”, in N. G. Mankiw (1994) (ed.), Monetary Policy, The University of Chicago Press, Chicago, Il.

Bluedorn, J. and Leigh, D. (2011). Revisiting the Twin Deficits Hypothesis: The Effect of Fiscal Consolidation on the Current Account. IMF Economic Review, 59, pp. 582-602.

Branson, W. (1983). Economic Structure and External Balance. IMF Staff Papers, 30, pp. 39-66.

Brecher, Richard A. (1974). Minimum Wage Rates and the Pure Theory of International Trade. Quarterly Journal of Economics, 5S( 1), pp. 98-116.

Buiter, W. (1988). Structural and Stabilization Aspects of Fiscal and Financial Policy in the Dependent Economy. Oxford Economic Papers, 40, pp. 220-245.

Chinn, M. and Prasad, E. (2003). Medium Term Determinants of Current Account Deficits in Industrial and Developing Countries: An Empirical Exploration. Journal of International Economics, 59, pp. 4776.

Chinn, M and Ito, H. (2007). Current Account Balances, Financial Development and Institutions: Assaying the World 'Saving Glut'. Journal of International Money and Finance, 26, pp. 546-69.

Chinn, M. and Wei, S-J (2012), “A Faith-based Initiative Meets the Evidence: Does a Flexible Exchange Rate Regime Really Facilitate Current Account Adjustment?”, Review of Economics and Statistics,

Croke, H., S. Kamin and S. Leduc (2006). An Assessment of the Disorderly Adjustment Hypothesis for Industrial Economies, International Finance 9, 37-61.

Davis, D. R. (1998), Does European Unemployment Prop Up American Wages? National Labor Markets and Global Trade, AER, 88, 478-494.

de Paula, A., and Scheinkman, J.A. (2011). The Informal Sector: An Equilibrium Model and Some Empirical Evidence from Brazil. Review of Income and Wealth, 57, pp. S8- S26.

Debelle, G., and G. Galati (2007). Current Account Adjustment and Capital Flows. Review of International Economics 15:989-1013. 
Dornbusch, R,, Goldfajn, I. and Valdes, R. (1995): "Currency crises and collapses", Brookings Papers on Economic Activity, pp 219-70.

Edwards, S. (2004a), Financial openness, sudden stops, and current account reversals.

American Economic Review 94 (2): 59-64.

Edwards, S. (2004b), . Thirty years of current account imbalances, current account reversals, and sudden stops. Fourth Mundell-Fleming Lecture. IMF Staff Papers 51 (Special Issue): 1-49.

Edwards, S. (2007), Capital Controls, Sudden Stops, and Current Account Reversals, in S. Edwards (ed.) Capital Controls and Capital Flows in Emerging Economies: Policies, Practices and Consequences, University of Chicago Press.

Endegnanew, Y., Amo- Yartey, C., Turner- Jones, T. (2012). Fiscal Policy and the Current Account: Are Microstates Different? IMF Working Paper 12/51.

Engstrom, Per \& Bertil Holmlund, (2009). "Tax evasion and self-employment in a high-tax country: evidence from Sweden," Applied Economics, Taylor \& Francis Journals, vol. 41(19), pages 2419-2430

Frenkel, J., and Razin, A (1992), Fiscal Policies and the World Economy, $2^{\text {nd }}$ edition, The MIT Press

Freund, C. (2005). Current account adjustment in industrialized countries. Journal of International Money and Finance, 21, pp. 1278-1298.

Caroline Freund \& Frank Warnock, (2007). Current Account Deficits in Industrial Countries: The Bigger They Are, The Harder They Fall?, in R. H. Clarida (ed.), G7 Current Account Imbalances: Sustainability and Adjustment, pages 133-168 National Bureau of Economic Research, Inc.

Friedman, M. (1953). Essays in Positive Economics, University of Chicago Press.

Gordon, Robert J., and Stephen R. King. (1982). The output cost of disinflation in traditional and vector autoregressive models. Brookings Papers on Economic Activity 1 : 205-42.

IMF (2013), IMF Multilateral Policy Issues Report, 2013 Pilot External Sector Report, International Monetary Fund, Washington, DC.

Keynes, J. M. (1931). The Economic Consequences of Mr. Churchill, in Essays in Persuasion: The Collected Writings of John Maynard Keynes, MacMillan.

Kim, S, and Roubini, N. (2008). Twin Deficits or Twin Divergence? Fiscal Policy, Current Account, and Real Exchange Rate in the U.S.. Journal of International Economics, 74, pp. 362-83.

Kleven, Henrik, Martin Knudsen, Claus Kreiner, Soren Pedersen, and Emmanuel Saez (2011). Unwilling or Unable to Cheat? Evidence from a Tax Audit Experiment in Denmark, Econometrica 79(3), 651 - 692.

Milesi-Feretti, G. M, and Razin, A. (1998). Sharp Reductions in Current Account Deficits: An Empirical Analyis, European Economic Review, vol 42, 3-5, 897-908.

Milesi-Feretti, G. M, and Razin, A. (2000), Current Account Reversals and Currency Crises: Empirical Regularities, in P. Krugman, ed., Currency Crises, Cambridge, MA: University of Chicago Press, 285326. 
Mussa, Michael (1986). "Nominal Exchange Rate Regimes and the Behavior of Real Exchange Rates, Evidence and Implications.” Carnegie-Rochester Conference Series on Public Policy, Vol. 25, pp. 117213.

Obstfeld, M. and Roggoff, K. (1996). Foundations of International Macroeconomics, The MIT Press.

Obstfeld, M. and Rogoff, K. (2004). The Unsustainable US Current Account Position Revisited. NBER Working Papers No. 10869, National Bureau of Economic Research.

Okun, Arthur M. (1978). Efficient disinflationary policies. American Economic Review 68 (May): 348-52.

F. Pappadà and Y. Zylberberg (2015), “Austerity Plans and Tax Evasion : Theory and Evidence from Greece,” Document De Travail N 546, Bank of France.

Perotti, R., Strauch, R. and von Hagen, J. (1998). Sustainable Public Finances. CEPR Discussion Paper 1781. Centre for Economic Policy Research.

Pissarides, C and G Weber (1989), An Expenditure-Based Estimate of Britain’s Black Economy, Journal of Public Economics 39, 17-32.

Rose, A. K. (2011), Exchange rate regimes in the modern era: Fixed, floating, and flaky, Journal of Economic Literature, 49, pp. 652-672.

Rousseeuw, P. J., Yohai, V. (1987). Robust Regression by Means of S-estimators in Robust and Nonlinear Time Series Analysis: 256-272, J. Franke, W. Hardle and D. Martin (eds). Berlin: Springer Verlag.

Schneider, F., Buehn, A. and Montenegro, C.E. (2010). Shadow economies all over the world: new estimates for 162 countries from 1999 to 2007. Policy Research Working Paper No. 5356, World Bank.

Slemrod, J. and Yitzhaki, S. (2002). Tax avoidance, evasion, and administration. In A.J. Auerbach and M. Feldstein (eds) Handbook of Public Economics, Vol. 3, pp. 1423-1470, Elsevier.

Tsibouris, G.C., Horton, M.A., Flanagan, M.J. and Maliszewski, W.S. (2006). Experience with Large Fiscal Adjustments. IMF Occasional Paper No. 246, International Monetary Fund.

World Bank (2011). World Development Indicators, World Bank.

Yohai, V. (1987). High Breakdown-point and High Efficiency Estimates for Regression. The Annals of Statistics, 15, 642-665. 


\section{Appendix}

\section{Adjustment Episodes}

\begin{tabular}{|c|c|c|c|c|c|c|c|}
\hline Country & Start & End & $\begin{array}{l}\text { Sacrifice } \\
\text { Ratio }\end{array}$ & Country & Start & End & $\begin{array}{l}\text { Sacrifice } \\
\text { Ratio }\end{array}$ \\
\hline Belgium & 1981 & 1984 & 1.084 & Malaysia & 1997 & 1999 & 0.3719 \\
\hline Canada & 1981 & 1984 & 1.546 & Paraguay & 1997 & 1999 & 0.340 \\
\hline Ireland & 1981 & 1988 & 1.404 & Philippines & 1997 & 2000 & 4.022 \\
\hline Kenya & 1981 & 1984 & 2.032 & Argentina & 1998 & 2002 & 1.436 \\
\hline Portugal & 1981 & 1986 & 0.740 & Chile & 1998 & 2001 & 3.121 \\
\hline Colombia & 1983 & 1987 & 1.122 & Ecuador & 1998 & 2000 & 0.341 \\
\hline $\begin{array}{l}\text { New } \\
\text { Zealand }\end{array}$ & 1984 & 1990 & 1.067 & Peru & 1998 & 2001 & 2.022 \\
\hline Greece & 1985 & 1988 & 0.294 & Venezuela & 1998 & 2000 & -0.231 \\
\hline Denmark & 1986 & 1989 & 1.174 & Yemen & 1998 & 2000 & 0.297 \\
\hline Bangladesh & 1988 & 1992 & 2.474 & $\begin{array}{l}\text { New } \\
\text { Zealand }\end{array}$ & 1999 & 2002 & 1.592 \\
\hline Benin & 1988 & 1991 & 0.769 & Guinea & 2000 & 2003 & 0.962 \\
\hline El Salvador & 1989 & 1994 & 1.348 & Sri Lanka & 2000 & 2003 & 1.650 \\
\hline Jamaica & 1989 & 1994 & 0.141 & Brazil & 2001 & 2004 & 1.048 \\
\hline Finland & 1991 & 1995 & 0.982 & Cameroon & 2001 & 2005 & 3.235 \\
\hline Burundi & 1992 & 1995 & 0.834 & Eritrea & 2001 & 2003 & -0.245 \\
\hline Rwanda & 1993 & 1995 & 0.701 & Tunisia & 2001 & 2004 & 4.297 \\
\hline Tunisia & 1993 & 1998 & 2.731 & Bolivia & 2002 & 2004 & 0.535 \\
\hline Jordan & 1994 & 1998 & 2.212 & Syria & 2003 & 2006 & 0.932 \\
\hline Mexico & 1994 & 1997 & 1.494 & Thailand & 2005 & 2007 & 0.564 \\
\hline Algeria & 1995 & 1998 & 0.479 & Guatemala & 2007 & 2011 & 2.468 \\
\hline $\begin{array}{l}\text { Cote } \\
\text { d'Ivoire }\end{array}$ & 1995 & 1998 & 1.720 & Ireland & 2008 & 2011 & 0.683 \\
\hline Thailand & 1995 & 1999 & 0.715 & Pakistan & 2008 & 2012 & 1.007 \\
\hline Vietnam & 1995 & 2001 & 1.505 & Peru & 2008 & 2011 & 2.750 \\
\hline Pakistan & 1996 & 2000 & 1.940 & Vietnam & 2008 & 2012 & 0.444 \\
\hline Colombia & 1997 & 2000 & 0.981 & Zambia & 2008 & 2010 & 0.797 \\
\hline
\end{tabular}

